\title{
Динаміка балансу антиоксидантно-проокидантних механізмів у внутрішніх органах під впливом артеріального джгута і реперфузї кінцівки
}

\begin{abstract}
Мета роботи: з’ясувати вплив двогодинного застосування артеріального джгута і реперфузії кінцівки на динаміку антиоксидантно-прооксидантних механізмів у печінці, легенях і нирці.

Матеріали і методи. Експерименти виконано на 36 нелінійних щурах-самцях масою 200-220 г. У дослідних групах під тіопентало-натрієвим знеболюванням (40 мг·к $\left.\Gamma^{-1}\right)$ проксимально на ліву лапку накладали смужку джгута “SWAT-T” шириною 1 см на 120 хв. Тварин дослідних груп виводили з експерименту через 60 хв, 120 хв, 24 год, 7 і 14 діб після реперфузії. У контрольній групі тварин вводили в наркоз, застосовуючи еквівалентну дозу тіопенталу натрію, накладали джгут без припинення кровотоку і в подальшому виводили з експерименту через 2 год. Для дослідження брали печінку, нирку та легені. У гомогенатах зазначених органів визначали вміст реагентів до тіобарбітурової кислоти (ТБК-активних продуктів ПОЛ), активність каталази. За співвідношенням активність каталази / вміст ТБК-активних продуктів ПОЛ розраховували антиоксидантно-прооксидантний індекс (АПІ). Результати досліджень та їх обговорення. У контролі інтенсивність ліпопероксидації і активність каталази збільшувалися від печінки до нирки і легень. Після реперфузії кінцівки в досліджуваних органах відмічали зростання інтенсивності ліпідної пероксидації, про що свідчило накопичення ТБК-активних продуктів, яке в печінці було вірогідно більшим, ніж у контролі, до 14-ї доби, в легенях - до 7-ї доби, в нирці - протягом 24 год. Активність каталази в органах була істотно більшою від контролю у всі терміни спостереження з максимумом через 24 год. Показник був вірогідно більшим у нирці. Величина АПІ в нирці і легенях підвищувалася до 24 год після реперфузії кінцівки і до 14-ї доби знижувалася, не досягаючи рівня контролю. В печінці динаміка показника була коливальною з першим підвищенням через 1 год, зниженням - через 2 год і подальшим зростанням до 14-ї доби. Наведені дані вказують на тривале напруження адаптаційно-компенсаторних механізмів, спрямованих на усунення патогенних чинників, зумовлених накладанням джгута, двогодинною ішемією та подальшою реперфузією кінцівки. Отримані результати вимагають подальшого поглибленого вивчення, проте вже тепер вказують на небезпечність двогодинного накладання джгута з позиції системного впливу на організм і вимагають додаткових заходів профілактики та корекції.

Реперфузія кінцівки після двогодинного артеріального джгута супроводжується тривалою активацією процесів ліпідної пероксидації у печінці, нирках і легенях, що проявляється статистично вірогідним зростанням вмісту ТБК-активних продуктів, який в печінці перевищує контрольний рівень до 14-ї доби після реперфузії, в нирці - через 24 год, в легенях - через 7 діб. Посилення процесів ПОЛ відбувається на тлі підвищення активності каталази у всіх органах, яка досягає максимуму через 24 год і не знижується до рівня контролю через 14 діб. Баланс антиоксидантно-прооксидантних процесів в досліджуваних органах зміщений в бік посилення антиоксидантних механізмів, що вказує на тривалий оксидативний стрес в постреперфузійному періоді.
\end{abstract}

Ключові слова: джгут; реперфузія; ліпопероксидація; внутрішні органи.

Постановка проблеми і аналіз останніх досліджень та публікацій. Проблемою останнього десятиліття стало зростання частоти терористичних атак і локальних збройних конфліктів [8]. В цих умовах основною причиною загибелі людей у 80-90 \% випадків стали масивна крововтрата 3 кінцівок та шок [7]. Своєчасне і правильне накладання артеріального джгута визнано найефективнішим засобом зупинки масивної зовнішньої кровотечі [6]. В екстремальних ситуаціях джгут накладається проксимально на кінцівку на термін до 2-х год, який вважається умовно безпечним.

В поодиноких публікаціях наведено результати, які ставлять під сумнів “безпечність” для організму зупинки артеріального кровотоку в кінцівці протягом 2-х год. Ускладнення артеріального джгута відмічали у 19 з 22 військовослужбовців із загрозливими пораненнями в Іраку й Афганістані (ампутація кінцівки, пошкодження шкіри, нервів і судин під джгутом, рабдоміоліз із розвитком гострої ниркової недостатності) [5]. Значну небезпеку становить реперфузія ішемізованої кінцівки, що сприяє розвитку запалення індукованих пошкодженням локальних ділянок і вторинному пошкодженню життєво важливих органів [11]. У роботі [9] показано, що реперфузійне пошкодження органів і тканин виникає вже через 60 хв після локальної ішемії.

Одним із провідних механізмів пошкодження після ішемії/реперфузії є генерація активних форм кисню (АФК), які ініціюють пероксидне окиснення ліпідів (ПОЛ) [4]. В умовах недостатності антиоксидантного захисту відмічається виражене пошкодження клітинних мембран внаслідок пероксидації їх ліпідного біошару.

Мета роботи: 3'ясувати вплив двогодинного застосування артеріального джгута і реперфузії кінцівки на баланс антиоксидантно-прооксидантних механізмів у печінці, легенях і нирці. 
Матеріали і методи. Експерименти виконано на 36 нелінійних щурах-самцях масою 200-220 г із дотриманням правил “Європейської конвенції захисту хребетних тварин, яких використовують з експериментальною та іншою науковою метою” (European Convention, 1984). Усіх тварин розділили на дві групи: контрольну і п’ять дослідних (по 6 тварин у кожній групі). У дослідних групах під тіопентало-натрієвим знеболюванням (40 мг·кГ $\left.{ }^{-1}\right)$ тваринам проксимально на ліву лапку накладали джгут на 120 хв. Застосовували смужку еластичного джгута "SWAT-T" (США) шириною 10 мм, що відповідає ширині джгута при накладанні на стегно дорослій людині. Такий джгут характеризується мінімальним негативним впливом на підлеглі тканини за рахунок своєї ширини і тривалим у часі больовим порогом [10]. Джгут затягували відповідно до нанесеного на ньому індикатора ефективного тиску, який припиняє кровотік. Дадатково здійснювали контроль якості накладання за допомогою реографічного методу. Характерною рисою джгута “SWAT-T” $є$ ефективна зупинка артеріального кровотоку протягом усього терміну експерименту [10]. Тварин дослідних груп виводили з експерименту в умовах тіопентало-натрієвого наркозу (60 мг·кг-1) методом тотального кровопускання із серця через 60 хв, 120 хв, 24 год, 7 і 14 діб після реперфузії. У контрольній групі тварин вводили в наркоз, застосовуючи еквівалентну дозу тіопенталу натрію, накладали джгут без припинення кровотоку і в подальшому виводили з експерименту через 2 год. Для дослідження брали печінку, нирку та легені. У гомогенатах зазначених органів визначали вміст реагентів до тіобарбітурової кислоти (ТБК-активних продуктів ПОЛ) - одного із основних скринінгових показників ліпідної пероксидації [2] і активність каталази - ключового компонента ферментативної ланки антиоксидантного захисту [3]. На основі цих даних розраховували антиоксидантно-прооксидантний індекс (АПІ = активність каталази / вміст
ТБК-активних продуктів ПОЛ) (А. П. Левицький та ін., 2006) [1]. Він належить до чутливих індикаторів стану антиоксидантного захисту та відображає баланс між антиоксидантними і прооксидантними механізмами. Вірогідність відмінностей між контрольною і дослідними групами оцінювали 3 використанням непараметричного критерію Манна-Уїтні. Відмінності вважали істинними при вірогідності нульової гіпотези менше 5 \% $(\mathrm{p}<0,05)$.

Результати досліджень та їх обговорення. Аналіз інтенсивності процесів ліпідної пероксидації показав, що інтенсивність ПОЛ, яку визначали за вмістом ТБК-активних продуктів (табл. 1), у контрольній групі виявилася найвищою в легенях, далі - в нирці і печінці (відмінності у всіх випадках статистично вірогідні $\left(\mathrm{p}_{1,2,3}<0,05\right)$.

Після реперфузії кінцівки (табл. 1, рис. 1) вміст ТБК-активних продуктів ПОЛ у печінці порівняно з контролем був статистично вірогідно більшим у всі терміни спостереження $(\mathrm{p}<0,05)$. Показник досягав максимуму через 2 год із моменту реперфузії (у 4,46 раза, $\mathrm{p}<0,05)$ і в подальшому знижувався та був істотно меншим, ніж через 1, 2 і 24 год після реперфузії $(\mathrm{p}<0,05)$. Проте через 14 діб статистично вірогідно перевищував контрольний рівень на 30,0 \% $(\mathrm{p}<0,05)$.

У нирці вміст ТБК-активних продуктів ПОЛ був статистично вірогідно більшим порівняно 3 контролем до 24 год після реперфузії кінцівки 3 максимумом через 1 год (у 2,08 раза порівняно 3 контролем, $\mathrm{p}<0,05)$. Починаючи з 7-ї доби, показник досягав рівня контролю (p>0,05) і з цього терміну був статистично вірогідно меншим, ніж через 1 і 2 год спостереження $(\mathrm{p}<0,05)$.

У легенях вміст ТБК-активних продуктів ПОЛ статистично вірогідно перевищував контроль до 7-ї доби з моменту реперфузії ( $<0,05)$, досягаючи максимуму через 2 год (на 96,9 \%, p $<0,05$ ). Через 14 діб показник перебував на рівні контролю $(\mathrm{p}>0,05)$.

Таблиця 1. Вплив артеріального джгута і реперфузії кінцівки на вміст ТБК-активних продуктів пОЛ (мкмоль· кг-1) у внутрішніх органах $(\mathrm{M} \pm \mathrm{m})$

\begin{tabular}{|c|c|c|c|c|c|c|}
\hline \multirow[b]{2}{*}{ Орган } & \multirow[b]{2}{*}{$\begin{array}{c}\text { Контроль } \\
\quad(n=6)\end{array}$} & \multicolumn{5}{|c|}{ Час реперфузії } \\
\hline & & $\begin{array}{l}1 \text { год } \\
(\mathrm{n}=6)\end{array}$ & $\begin{array}{l}2 \text { год } \\
(\mathrm{n}=6)\end{array}$ & $\begin{array}{c}24 \text { год } \\
(\mathrm{n}=6)\end{array}$ & $\begin{array}{l}7 \text { діб } \\
(n=6)\end{array}$ & $\begin{array}{l}14 \text { діб } \\
(\mathrm{n}=6)\end{array}$ \\
\hline Печінка & $0,50 \pm 0,01$ & $0,79 \pm 0,03^{*}$ & $2,23 \pm 0,10^{*}$ & $0,96 \pm 0,04^{*}$ & $0,71 \pm 0,04^{*}$ & $0,65 \pm 0,03^{*}$ \\
\hline Нирка & $0,84 \pm 0,03$ & $1,75 \pm 0,09^{*}$ & $1,25 \pm 0,04^{*}$ & $0,96 \pm 0,03^{*}$ & $0,90 \pm 0,04$ & $0,91 \pm 0,04$ \\
\hline Легені & $0,98 \pm 0,04$ & $1,43 \pm 0,07^{*}$ & $1,93 \pm 0,12^{*}$ & $1,49 \pm 0,05^{*}$ & $1,34 \pm 0,07^{*}$ & $0,94 \pm 0,05$ \\
\hline $\mathrm{p}_{1}$ & $<0,05$ & $<0,05$ & $<0,05$ & $>0,05$ & $<0,05$ & $<0,05$ \\
\hline $\mathrm{p}_{2}$ & $<0,05$ & $<0,05$ & $>0,05$ & $<0,05$ & $<0,05$ & $<0,05$ \\
\hline $\mathrm{p}_{3}$ & $<0,05$ & $<0,05$ & $<0,05$ & $<0,05$ & $<0,05$ & $>0,05$ \\
\hline
\end{tabular}

Примітка. * - відмінності стосовно контрольної групи статистично вірогідні; р - відмінності величини показника в печінці й нирках; $\mathrm{p}_{2}$ - відмінності величини показника в печінці й легенях; $\mathrm{p}_{3}$ - відмінності величини показника в легенях і нирках. 


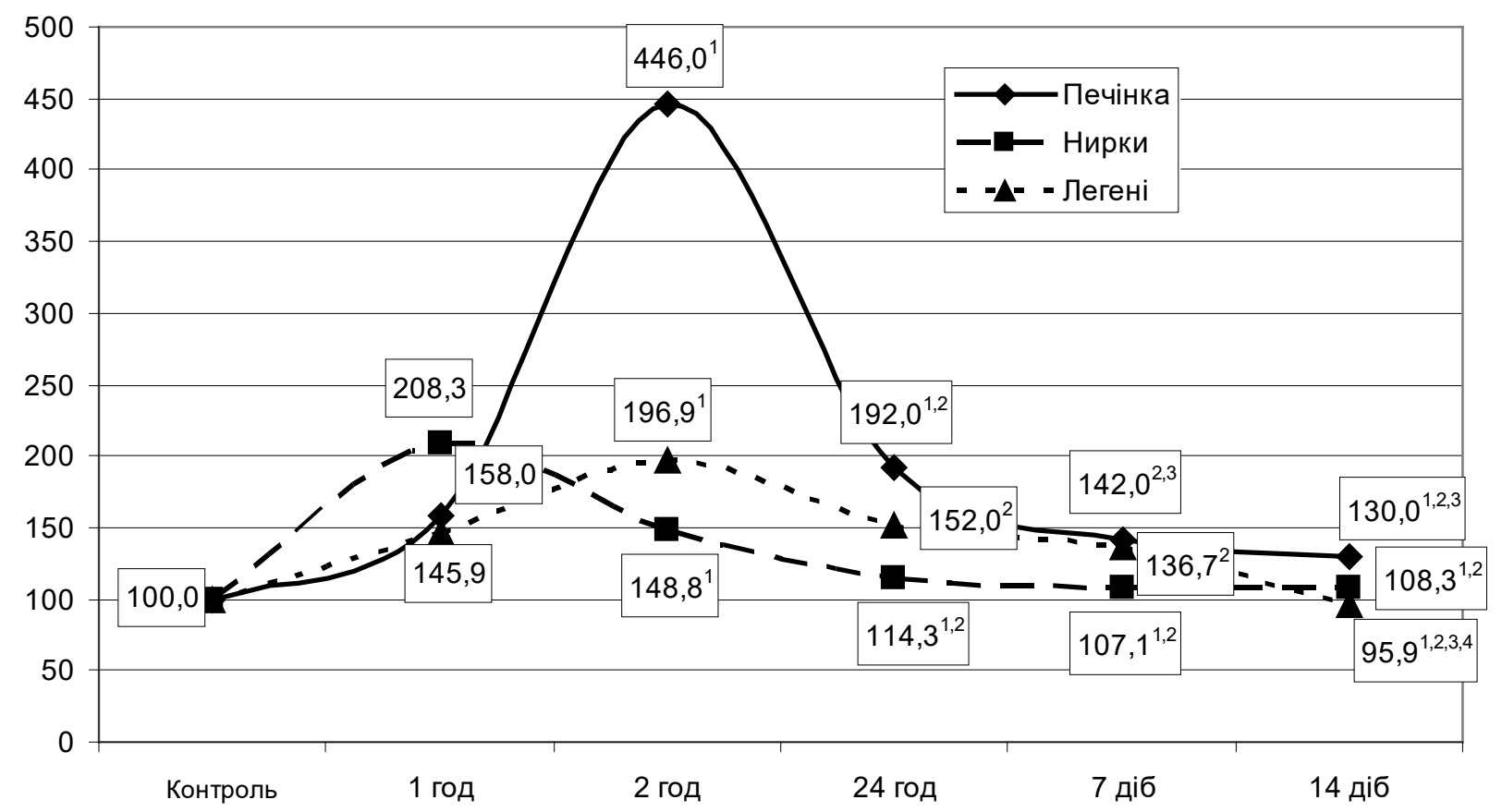

Рис. 1. Динаміка вмісту ТБК-активних продуктів ПОЛ (у відсотках від рівня контролю) в печінці, нирках і легенях під впливом артеріального джгута і реперфузії кінцівки (примітка: 1,2,3,4 - відмінності, відповідно, порівняно з 1 год, 2 год, 24 год, 7 добою і 14 добою статистично вірогідні, p<0,05).

Порівнюючи інтенсивність ПОЛ у досліджуваних органах в різні терміни після реперфузії кінцівки, з'ясувалося, що через 1 год показник ставав статистично вірогідно більшим у нирці, далі - легенях і печінці (у всіх випадках $\mathrm{p}_{1,2,3}<0,05$ ). Через 2 год після реперфузії кінцівки показник перевищував у печінці й легенях і був, відповідно, на 78,4 і 54,4 \% більшим, ніж у нирці $\left(\mathrm{p}_{1,3}<0,05\right)$. У подальшому - через 24 год - 7 діб вміст ТБК-активних продуктів ПОЛ був статистично вірогідно більшим у легенях $\left(\mathrm{p}_{2,3}<0,05\right)$. Через 7-14 діб показник виявився найменшим у печінці $\left(\mathrm{p}_{1,2}<0,05\right)$. Через 14 діб величина показника в нирці і легенях була майже однаковою $\left(\mathrm{p}_{3}>0,05\right)$ і статистично вірогідно більшою, ніж у печінці $\left(\mathrm{p}_{1,2}<0,05\right)$.

Активність каталази (табл. 2) у контрольній групі виявилася пропорційна до вмісту ТБК-активних продуктів ПОЛ і була, відповідно, най- більшою в легенях, далі - в нирках і печінці (у всіх випадках $\left.\mathrm{p}_{1,2,3}<0,05\right)$.

Після реперфузії кінцівки (табл. 2, рис. 2) у печінці активність каталази наростала до 24 год спостереження і в цей термін у 16,35 раза перевищувала рівень контролю $(\mathrm{p}<0,05)$ та була істотно більшою порівняно з попередніми термінами спостереження $(\mathrm{p}<0,05)$. У подальшому показник знижувався, проте через 14 діб він продовжував перевищувати контроль у 14,05 раза $(\mathrm{p}<0,05)$.

У нирці активність каталази теж перевищувала контроль у всі терміни після реперфузії кінцівки $(\mathrm{p}<0,05)$, досягала максимуму через 24 год і була більшою порівняно з контролем у 9,85 раза $(\mathrm{p}<0,05)$. Знижуючись до 14-ї доби, показник не досягав рівня контролю і залишався статистично вірогідно більшим у 4,16 раза $(\mathrm{p}<0,05)$.

Таблиця 2. Вплив артеріального джгута і реперфузії кінцівки на активність каталази (мккат·кг-1) внутрішніх органів $(\mathrm{M} \pm \mathrm{m})$

\begin{tabular}{||l|c|c|c|c|c|c||}
\hline \hline \multirow{2}{*}{ Орган } & \multirow{2}{*}{$\begin{array}{c}\text { Контроль } \\
(\mathrm{n}=6)\end{array}$} & \multicolumn{5}{|c||}{ Час реперфузії } \\
\cline { 3 - 7 } & 1 год & 2 год & 24 год & 7 діб & 14 діб \\
\hline Печінка & $0,51 \pm 0,02$ & $3,93 \pm 0,10^{*}$ & $5,56 \pm 0,10^{*}$ & $8,34 \pm 0,15^{*}$ & $7,69 \pm 0,10^{*}$ & $7,17 \pm 0,16^{*}$ \\
\hline Нирка & $1,51 \pm 0,5$ & $4,85 \pm 0,15^{*}$ & $7,88 \pm 0,21^{*}$ & $9,85 \pm 0,22^{*}$ & $8,94 \pm 0,18^{*}$ & $6,28 \pm 0,14^{*}$ \\
\hline Легені & $1,69 \pm 0,07$ & $2,06 \pm 0,10^{*}$ & $4,52 \pm 0,14^{*}$ & $4,55 \pm 0,09^{*}$ & $4,15 \pm 0,11^{*}$ & $3,79 \pm 0,14^{*}$ \\
\hline $\mathrm{p}_{1}$ & $<0,05$ & $<0,05$ & $<0,05$ & $<0,05$ & $<0,05$ & $<0,05$ \\
\hline $\mathrm{p}_{2}$ & $<0,05$ & $<0,05$ & $<0,05$ & $<0,05$ & $<0,05$ & $<0,05$ \\
\hline $\mathrm{p}_{3}$ & $<0,05$ & $<0,05$ & $<0,05$ & $<0,05$ & $<0,05$ & $<0,05$ \\
\hline
\end{tabular}




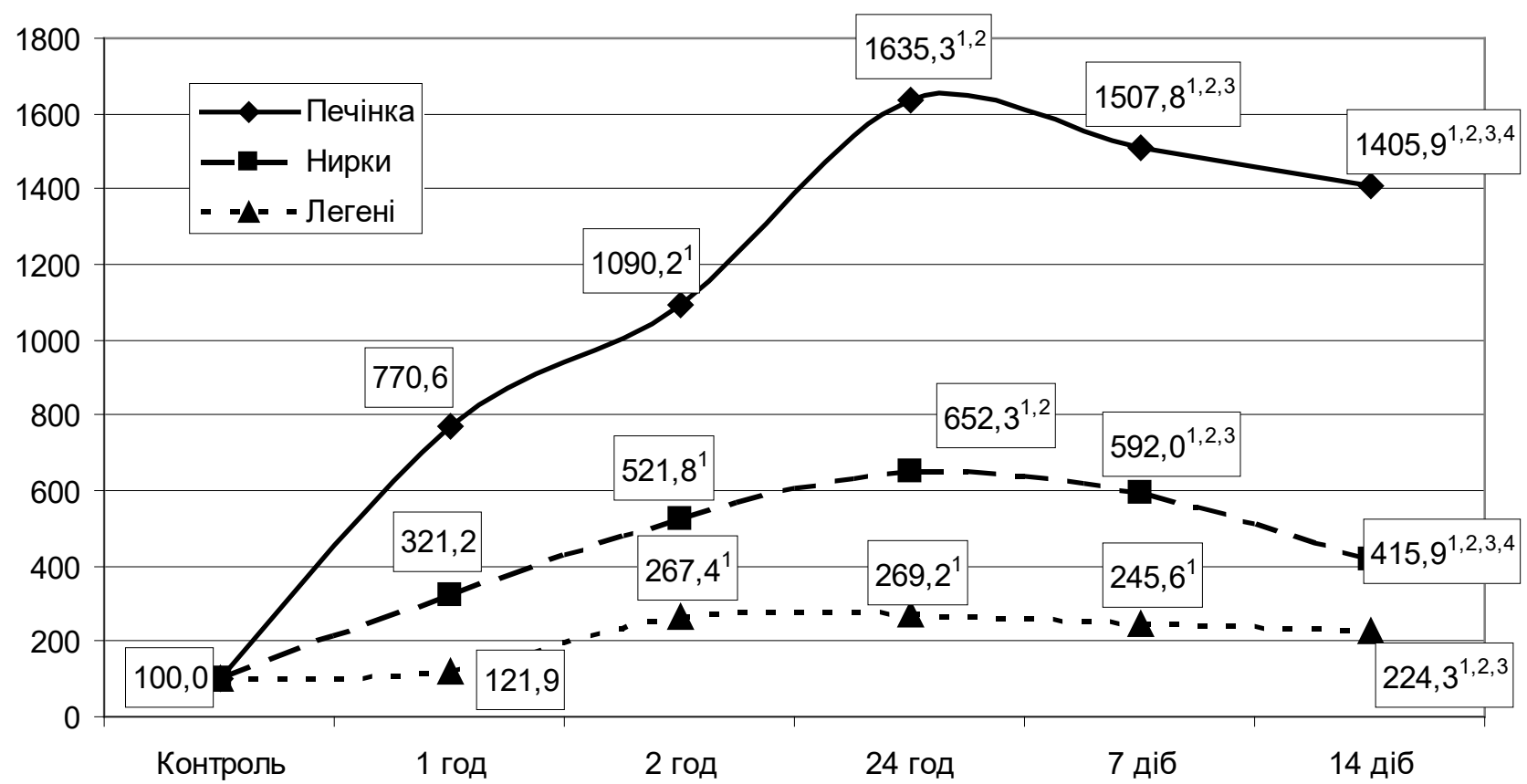

Рис. 2. Динаміка активності каталази (у відсотках від рівня контролю) в печінці, нирках і легенях під впливом артеріального джгута і реперфузії кінцівки.

У легенях активність каталази після реперфузії кінцівки статистично вірогідно перевищувала контроль у всі терміни спостереження $(\mathrm{p}<0,05)$. Показник досягав максимуму через 2 год після реперфузії кінцівки (у 2,67 раза, $\mathrm{p}<0,05)$ і залишався на практично такому ж рівні до 7-ї доби спостереження (p>0,05). Через 14 діб показник знижувався, що виявилося статистично вірогідним порівняно з 2 і 24 год спостереження $(\mathrm{p}<0,05)$, проте не досягав рівня контролю і залишався у 2,24 раза більшим $(\mathrm{p}<0,05)$.

Порівнюючи активність каталази у тканинах досліджуваних органів, з’ясували, що до 7-ї доби постреперфузійного періоду показник був статистично вірогідно більшим у нирці, далі - в печінці і найнижчим - у легенях $\left(\mathrm{p}_{1,2,3}<0,05\right)$. Через 14 діб активність каталази ставала істотно більшою у печінці, порівняно з іншими органами $\left(\mathrm{p}_{1,2}<0,05\right)$, і продовжувала залишатися найнижчою в легенях $\left(\mathrm{p}_{2,3}<0,05\right)$.
Наведена вище динаміка вмісту ТБК-активних продуктів ПОЛ і активності каталази не могла не позначитися на величині АПІ. У контролі (табл. 3) показник виявився статистично вірогідно більшим у нирці і легенях порівняно з печінкою (відповідно, на 76,7 і 68,0 \%, p<0,05).

Двогодинна ішемія задньої лапки щура з наступною реперфузією (табл. 3, рис. 3) вже через 1 год порівняно 3 контролем супроводжувалася статистично вірогідним зростанням величини АПІ печінки і нирок (відповідно, у 4,84 раза та 54,9 \%, $\mathrm{p}<0,05)$. У легенях величина досліджуваного показника, навпаки, знижувалася, проте результат виявився статистично не вірогідним (р>0,05).

Через 2 год після реперфузії величина АПІ печінки порівняно з попереднім терміном спостереження знижувалася $(\mathrm{p}<0,05)$, проте продовжувала залишатися істотно більшою, ніж у контрольній групі (у 2,45 раза, $\mathrm{p}<0,05)$. У подальшому показ-

Таблиця 3. Вплив артеріального джгута і реперфузії кінцівки на величину АПІ (ум. од.) печінки, нирок і легень (M \pm

\begin{tabular}{||l|c|c|c|c|c|c||}
\hline \hline \multirow{2}{*}{ Орган } & \multirow{2}{*}{$\begin{array}{c}\text { Контроль } \\
(\mathrm{n}=6)\end{array}$} & $\begin{array}{c}1 \text { Чод } \\
(\mathrm{n}=6)\end{array}$ & $\begin{array}{c}2 \text { год } \\
(\mathrm{n}=6)\end{array}$ & $\begin{array}{c}24 \text { год } \\
(\mathrm{n}=6)\end{array}$ & $\begin{array}{c}7 \text { діб } \\
(\mathrm{n}=6)\end{array}$ & $\begin{array}{c}14 \text { діб } \\
(\mathrm{n}=6)\end{array}$ \\
\hline Печінка & $1,03 \pm 0,02$ & $5,04 \pm 0,25^{*}$ & $2,52 \pm 0,12^{*}$ & $8,78 \pm 0,27^{*}$ & $11,02 \pm 0,58^{*}$ & $11,23 \pm 0,63^{*}$ \\
\hline Нирка & $1,82 \pm 0,11$ & $2,82 \pm 0,12^{*}$ & $6,32 \pm 0,25^{*}$ & $10,33 \pm 0,45^{*}$ & $10,07 \pm 0,44^{*}$ & $6,95 \pm 0,35^{*}$ \\
\hline Легені & $1,73 \pm 0,06$ & $1,46 \pm 0,11$ & $2,40 \pm 0,21^{*}$ & $3,06 \pm 0,08^{*}$ & $3,14 \pm 0,06^{*}$ & $4,09 \pm 0,15^{*}$ \\
\hline $\mathrm{p}_{1}$ & $<0,05$ & $<0,05$ & $<0,05$ & $<0,05$ & $>0,05$ & $<0,05$ \\
\hline $\mathrm{p}_{2}$ & $<0,05$ & $<0,05$ & $>0,05$ & $<0,05$ & $<0,05$ & $<0,05$ \\
\hline $\mathrm{p}_{3}$ & $>0,05$ & $<0,05$ & $<0,05$ & $<0,05$ & $<0,05$ & $<0,05$ \\
\hline
\end{tabular}




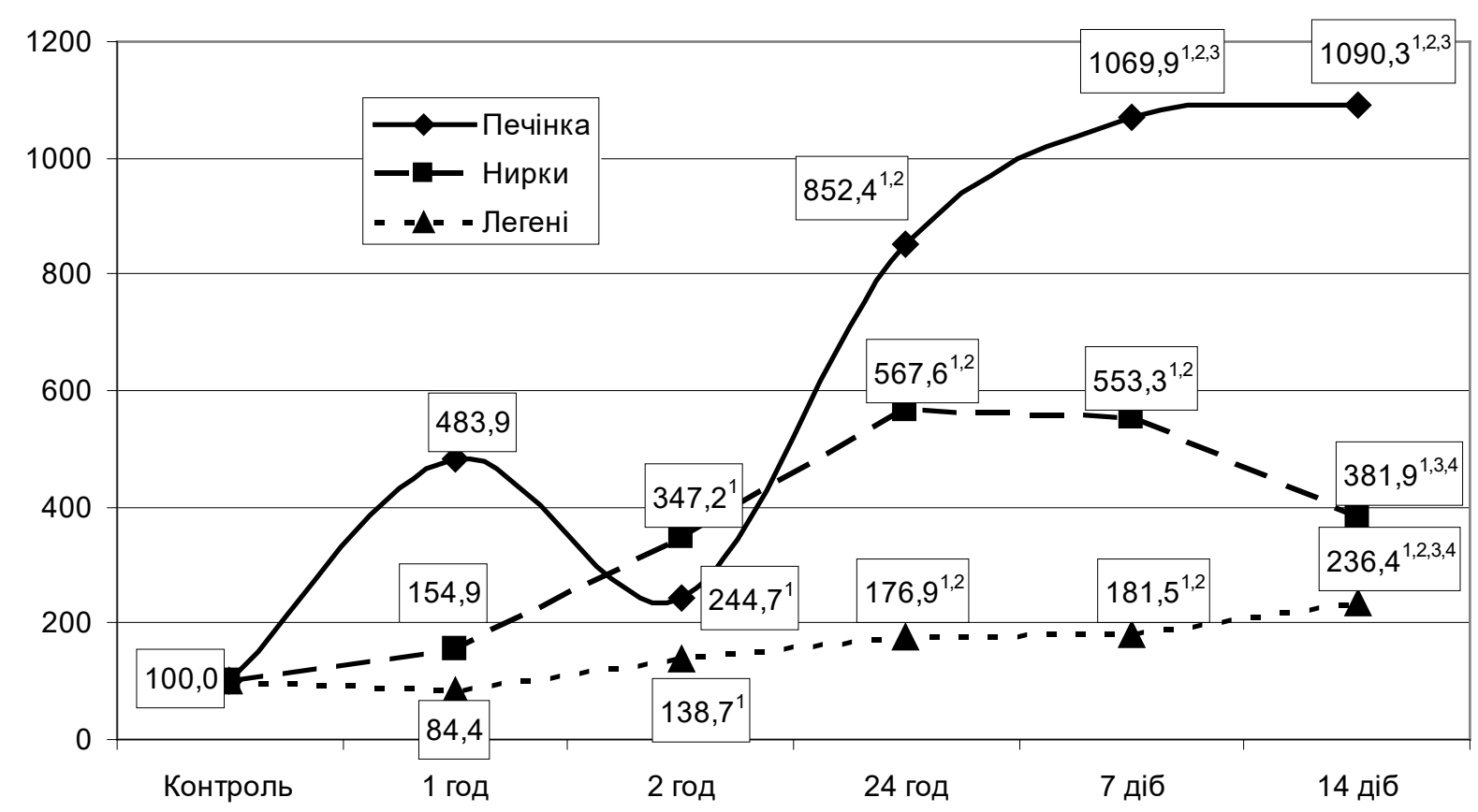

Рис. 3. Динаміка величини АПІ (у відсотках від рівня контролю) печінки, нирок і легень під впливом артеріального джгута і реперфузії.

ник стрімко зростав і через 24 год після реперфузії перевищував контроль у 8,52 раза $(\mathrm{p}<0,05)$, через 7 діб - досягав максимуму (у 10,70 раза, p $<0,05)$ i залишався на такому ж рівні до 14-ї доби.

У нирці через 2 год після реперфузії величина АПІ продовжувала зростати, що виявилося статистично значущим, порівняно $з$ попереднім терміном спостереження $(\mathrm{p}<0,05)$. Через 24 год після реперфузії показник досяг максимуму й у 5,68 раза перевищував контрольний рівень $(\mathrm{p}<0,05)$. Через 7 діб після реперфузії величина АПІ нирки залишалася на рівні 24 год (р>0,05), проте до 14-ї доби статистично вірогідно знижувалася порівняно $з 24$ год і 7-ю добою $(\mathrm{p}<0,05)$. У цей термін показник продовжував залишатися суттєво більшим, ніж у контролі (у 3,82 раза, $\mathrm{p}<0,05)$ та порівняно 3 1 год спостереження (у 2,46 раза, $\mathrm{p}<0,05$ ).

У легенях, починаючи з 2 год після реперфузії, показник поступово зростав і через 2 год ставав більшим, ніж у контролі, на 38,7 \%, через 24 год на 76,9 \%, через 7 діб - на 81,5 \%, через 14 діб - у 2,36 раза (у всіх випадках $\mathrm{p}<0,05$ ).

Порівняння величини АПІ в печінці, нирках і легенях показало, що через 1 год реперфузії показник, навпаки, виявився найбільшим у печінці й на 78,7 \% перевищував рівень АПІ в нирці $(\mathrm{p}<0,05)$ i в 3,45 раза порівняно з легенями $(\mathrm{p}<0,05)$. Через 2 год реперфузії величина АПІ ставала істотно більшою в нирці, порівняно з іншими досліджуваними органами - у 2,51 раза стосовно печінки $(\mathrm{p}<0,05)$ й у 2,63 раза стосовно легень $(\mathrm{p}<0,05)$.
Через 24 год реперфузії показник продовжував бути статистично вірогідно більшим у нирці (на 17,6 \% порівняно з печінкою, p<0,05 і в 3,38 раза порівняно з легенями, $\mathrm{p}<0,05)$. Через 7 діб величина АПІ в печінці і нирках ставала майже однаковою $(\mathrm{p}>0,05)$ і була істотно більшою, ніж у легенях (відповідно, у 3,51 і 3,21 раза, $\mathrm{p}<0,05)$. Через 14 діб величина АПІ в досліджуваних органах ставала різною: найбільшою - в печінці, нирці і далі - в легенях ( $<<0,05$ між групами спостереження).

Таким чином, у нормі інтенсивність ліпопероксидації і активність каталази збільшуються від печінки до нирки і легень, що, очевидно, пов'язано із функціональним розподілом інтенсивності ліпідної пероксидації, спрямованої на забезпечення необхідної пластичності біомембран, необхідної для оптимальної реалізації мембранозалежних функцій. У цих умовах навіть підвищена активність каталази не перешкоджає високій інтенсивності ПОЛ. Можна припустити, що надмірність активації каталази при наявності чинників, які стимулюють ПОЛ, є важливим захисним механізмом.

Після реперфузії кінцівки в досліджуваних органах відмічається зростання інтенсивності ліпідної пероксидації, про що свідчить накопичення ТБК-активних продуктів. Ці дані вказують на виражений системний вплив ендотоксинів і активних форм кисню, які утворюються в ішемізованій кінцівці протягом 2-х год, і в подальшому потрапляють у системний кровотік. За терміном нормалізації вмісту ТБК-активних продуктів ПОЛ ор- 
гани розподіляються так: нирка $\leftarrow$ легені $\leftarrow$ печінка, що вказує на різну резистентність органів до впливу ендотоксинів, які генеруються в умовах ішемії кінцівки. Разом з тим, насторожує тривалість підвищеної інтенсифікації ПОЛ: у печінці - до 14-ї доби, в легенях - до 7-ї доби, що не може не позначитись на їх функціональному стані, особливо при наявності супутніх механічних ушкоджень і крововтрати.

Вища резистентність нирки до постішемічного ендотоксикозу пов’язана з тим, що абсолютна активність каталази в цьому органі протягом 1 год-7 діб постреперфузійного періоду була найбільшою. Дещо менший абсолютний рівень і водночас найбільший приріст показника відмічався в печінці. На наш погляд, це пов’язано з детоксикаційною функцією печінки, адже в процесі оксидазних і оксигеназних реакцій, активації печінкових макрофагів інтенсифікується утворення активних форм кисню, що, у свою чергу, сприяє значній активації каталази [4]. Незважаючи на це, висока каталазна активність не компенсує підвищений вміст ТБК-активних продуктів ПОЛ. Звертає на себе увагу спалах активації ліпопероксидації в печінці, який відмічається через 2 год після реперфузії кінцівки. Він, очевидно, відображає недостатність компенсаторних процесів в органі, спрямованих на підтримання гомеостазу. Можна припустити, що в цей термін настає виснаження активності каталази, з подальшою експресією генів, спрямованих на їі додатковий синтез. На це вказує також і різке зниження через 2 год величини АПІ.

Слід зауважити, що величина АПІ, яка відображає баланс прооксидантних і антиоксидантних механізмів, до 14-ї доби не нормалізувалася в жодному із досліджуваних органів, що вказує на тривале в часі напруження адаптаційно-компенсаторних механізмів, спрямованих на усунення патогенних чинників, зумовлених накладанням джгута, двогодинною ішемією та подальшою ре-

\section{СПИСОК ЛІТЕРАТУРИ}

1. Антиоксидантно-прооксидантний індекс сироватки крові щурів з експериментальним стоматитом і його корекція зубними еліксирами / А. П. Левицький, В. М. Почтар, О. А. Макаренко, Л. І. Гридіна // Одеський мед. журн. - 2006. - № 1. - С. 22-25.

2. Доклінічні дослідження лікарських засобів : метод. рек. ; за ред. О. В. Стефанова. - К. : Авіценна, 2001. - 528 с.

3. Метод определения активности каталазы / М. А. Королюк, Л. И. Иванова, И. Г. Майорова, В. Е. Токарев // Лабораторное дело. - 1988. - № 1. - С. 16-19.

4. Нагорная Н. В. Оксидативный стресс: влияние на организм человека, методы оценки [Электронный ресурс] / Н. В. Нагорная, Н. А. Четверик // Здоров’я дитини. - 2010. № 2. - Режим доступа к журн. - http://www.mif-ua.com/archive/article/12762 перфузією кінцівки [1]. Враховуючи, що інтенсифікація процесів ПОЛ належить до одного із пускових механізмів системної відповіді організму на запалення, можна припустити суттєве зростання вірогідності розвитку поліорганної недостатності, особливо у випадку додаткових механічних пошкоджень і крововтрати, що має місце при тяжкій травмі чи вогнепальних пораненнях. Отриманий результат вимагає подальшого поглибленого вивчення, проте вже тепер вказує на небезпечність двогодинного накладання джгута з позиції системного впливу на організм і потребує додаткових заходів корекції.

Висновки. 1. Реперфузія кінцівки після двогодинного артеріального джгута супроводжується тривалою активацією процесів ліпідної пероксидації у печінці, нирках і легенях, що проявляється статистично вірогідним зростанням вмісту ТБК-активних продуктів ПОЛ з максимумом через 1 год після реперфузії в нирці і через 2 год - в печінці і легенях. В печінці показник не нормалізується до 14-ї доби після реперфузії, в нирці він досягає контрольного рівня через 24 год, в легенях - через 7 діб.

2. Посилення процесів ПОЛ відбувається на тлі підвищення активності каталази у всіх органах, яка досягає максимуму через 24 год і не знижується до рівня контролю через 14 діб.

3. Баланс антиоксидантно-прооксидантних процесів, навіть на тлі нормалізації вмісту вторинних продуктів ПОЛ, до 14-ї доби в досліджуваних органах зміщений у бік посилення антиоксидантних механізмів, що вказує на тривалий оксидативний стрес у постреперфузійному періоді.

Перспективи подальших досліджень. У перспективі передбачається оцінити ефективність препаратів 3 антиоксидантними властивостями для корекції виявлених порушень.

5. Clasper J. C. Limb complications following pre-hospital tourniquet use // J. C. Clasper, K. V. Brown, P. Hill // J. R. Army Med. Corps. 2009. - Vol. 155 (3). - P. 200-202.

6. Efficacy of prehospital application of tourniquets and hemostatic dressings to control traumatic external hemorrhage. - [Режим доступу] https://www.ems.gov/pdf/research/Studiesand-Reports.pdf

7. Elster Eric A. Implications of combat casualty care for mass casualty events / Eric A. Elster, Frank K. Butler, Todd E. Rasmussen // JAMA. - 2013. - Vol. 310(5). - P. 475-476.

8. Global Terrorism Index. - [Режим доступу] http:// economicsandpeace.org/wp-content/uploads/2015/11/2015Global-Terrorism-Index-Report.pdf 
9. Lee C. Tourniquet use in the civilian prehospital setting / C. Lee, K. M. Porter, T. J. Hodgetts // Emerg. Med. J. - 2007. Vol. 24(8). - P. 584-587.

10. Tourniquets and occlusion: the pressure of design / P. L. Wall, D. C. Duevel, M. B. Hassan [et al.] // Mil Med. - 2013.

\section{REFERENCE}

1. Levytskyi, A.P., Pochtar, V.M., Makarenko, O.A. \& Hrydina, L.I. (2006). Antyoksydantno-prooksydantnyi indeks syrovatky krovi shchuriv z eksperymentalnym stomatytom i yoho korektsiia zubnymy eliksyramy [Antioxidant-prooxidant index serum of rats with experimental stomatitis and its correction mouthwash]. Odeskyi medychnyi zhurnal - Odesa Medical Journal, 1, 22-25 [in Ukrainian].

2. Stefanov, O.V. (Ed.) (2001). Doklinichni doslidzhennia likarskykh zasobiv: metod. rek. [Preclinical studies of drugs: guidelines]. Kyiv: Avitsenna [in Ukrainian].

3. Koroliuk, M.A., Ivanova, L.I., Mayorova, I.H. \& V.E. Tokaryev (1988). Metod opredelieniia aktyvnosty katalazy [Method for the determination of catalase activity]. Laboratornoye delo - Laboratory work, 1, 16-19 [in Russian].

4. Nagornaya, N.V. \& Chetverik, N.A. (2010). Oksydatyvnyy stress: vliyaniye na organism cheloveka, metody otsenky [Oxidative stress: effects on the human body, methods of evaluation]. Zdorovia dytyny - Child's Health, 2. Retrieved from http://www. mif-ua.com/archive/article/12762 [in Russian].

5. Clasper, J.C., Brown, K.V. \& Hill, P. (2009). Limb
- Vol.178(5). - P. 578-587.

11. Wright G. Whould civilian pre-hospital emergency care provision include tourniquets for the management of uncontrolled traumatic haemorrhage? / G. Wright, V. S. Mcdonald, V. G. Smith // Australasian Journal of Paramedicine. - 2015. - Vol. 12(4). - P. 1-5.

complications following pre-hospital tourniquet use. J. R. Army Med Corps, 3, (155), 200-202.

6. Efficacy of prehospital application of tourniquets and hemostatic dressings to control traumatic external hemorrhage. - Retrieved from https://www.ems.gov/pdf/research/Studies-and-Reports.pdf 7. Elster A. Eric, Frank, K., Todd E. Rasmussen (2013). Butler, implications of combat casualty care for mass casualty events. JAMA, 5 (310), 475-476.

8. Global Terrorism Index. - Retrieved from http://economicsandpeace.org/wp-content/uploads/2015/11/2015-Global-Terrorism-Index-Report.pdf

9. Lee, C., Porter, K.M. \& Hodgetts T.J. (2007). Tourniquet use in the civilian prehospital setting. Emerg. Med. J., 8, (24), 584-587. 10. Wall, P.L., Duevel, D.C., Hassan, M.B., Welander, J.D., Sahr, S.M., \& Buising, C.M. (2013). Tourniquets and occlusion: the pressure of design. Mil. Med., 5, (178), 578-587.

11. Wright, G., Mcdonald, V.S. \& Smith, V.G. (2015). Would civilian pre-hospital emergency care provision include tourniquets for the management of uncontrolled traumatic haemorrhage? Australasian Journal of Paramedicine. 4, (12), 1-5.

\section{R. V. MAKSYMYV ${ }^{1}$, A. A. HUDYMA ${ }^{1}$, V. M. SYDORENKO²}

I. Horbachevsky Ternopil State Medical University ${ }^{1}$

O. Bohomolets National Medical University ${ }^{2}$

\section{DYNAMIC OF BALANCE OF ANTIOXIDANT-PROOXIDANT MECHANISM IN INTERNAL ORGANS UNDER THE INFLUENCE OF BLOOD HARNESSES AND LIMB REPERFUSION}

The aim of the work: clarification of the impact of a two-hour use of blood and reperfusion limb tourniquet on the dynamics of antioxidant-oxidative mechanisms in the liver, lung and kidney.

Materials and Methods. Experiments were performed on 36 non-linear male rats weighing 200-220. In the experimental group during anesthesia with tiopepntalo-sodium $\left(40 \mathrm{mg} \cdot \mathrm{kg}^{-1}\right)$ proximal to the left leg superimposed strip bundle «SWAT-T» $1 \mathrm{~cm}$ to $120 \mathrm{minutes}$. Animals of the research groups were taken out of the experiment, after 60 minutes, 120 minutes, 24 hours, 7 and 14 days after reperfusion. In the control group animals were injected with anesthesia using an equivalent dose of thiopental sodium tow imposed without stopping blood flow and subsequently taken out of the experiment after 2 hours. We studied liver, kidney and lungs. In homogenates of these reagents we determined the content of thiobarbituric acid (TBA-active products of lipid peroxidation), catalase activity. The ratio of catalase activity / content of TBA-active products of lipid peroxidation was calculated antioxidant-prooxidant index (API).

Results and Discussion. In controlling the intensity of lipid peroxidation and catalase activity increased from the liver to the kidneys and lungs. After reperfusion of limbs in the test bodies was noted increase in the intensity of lipid peroxidation, as evidenced by the accumulation of TBA-active products which the liver was significantly greater than in the control, 14 days in the lungs - up to 7 days in the kidney - within 24 hours. The activity of catalase in organs was significantly greater than controls in all periods of observation with a maximum of 24 hours. Score was significantly greater in the kidney. The value of API in the kidney and lungs increased to 24 hour after reperfusion of limbs and reduced to 14 days without reaching the level of control. In the liver oscillatory dynamics index was the first increase after 1 hour, reduced -2 hours and further increase to 14 days. These data indicate continued stress adaptation and compensatory mechanisms aimed at eliminating pathogenic factors caused by the imposition of tow a two-hour ischemia and subsequent reperfusion limbs. The results require further in-depth study, but are now pointing to the danger of imposing two-hour tow from the perspective of systemic effects on the body and require additional prevention and correction.

Reperfusion limbs after a two-hour arterial tourniquet is accompanied by prolonged activation of lipid peroxidation in the liver, kidneys and lungs, shown a statistically significant increase of the content of TBA-active products, which in the liver than the control level to the $14^{\text {th }}$ day after reperfusion in kidney - 24 hours in the lungs - after 7 days. Strengthening lipid peroxidation comes amid increased activity of catalase in all organs, which reaches a maximum after 24 hours and is not reduced to the level of control after 14 days. Balance of antioxidant-prooxidant processes in the studied organs shifted towards strengthening antioxidant mechanisms, which indicates oxidative stress in the long run postreperfusion.

Key words: harness; reperfusion; lipid peroxidation; internal organs. 


\section{Р. В. МАКСЫМИВ¹, А. А. ГУДЫМАํ, В. М. СИДОРЕНКО}

гВУз “Тернопольский государственный медицинский университет имени И. Я. Горбачевского” Национальный медицинский университет имени А. А. Богомольца ${ }^{2}$

\section{ДИНАМИКА БАЛАНСА АНТИОКСИДАНТНО-ПРООКСИДАНТНЫХ МЕХАНИЗМОВ ВНУТРЕННИХ ОРГАНОВ ПОД В.ИЯНИЕМ АРТЕРИАЛЬНОГО ЖКУТА И РЕПЕРФУЗИИ КОНЕЧНОСТИ}

Цель работы: выяснение влияния двухчасового применения артериального жгута и реперфузии конечности на динамику антиоксидантно-прооксидантных механизмов в печени, легких и почке.

Материалы и методы. Эксперименты выполнены на 36 нелинейных крысах-самцах массой 200-220 г. В исследуемых группах под тиопентало-натриевым наркозом $\left(40\right.$ мг·к $\left.\Gamma^{-1}\right)$ проксимально на левую лапку накладывали полоску жгута “SWAT-T” шириной 1 см на 120 мин. Животных опытных групп выводили из эксперимента через 60 мин, 120 мин, 24 ч, 7 и 14 суток после реперфузии. В контрольной группе животных вводили в наркоз, применяя эквивалентную дозу тиопентала натрия, накладывали жгут без прекращения кровотока и в дальнейшем выводили из эксперимента через 2 ч. Для исследования брали печень, почку и легкие. В гомогенатах указанных органов определяли содержание реагентов к тиобарбитуровой кислоте (ТБК-активных продуктов ПОЛ), активность каталазы. По соотношению активность каталазы / содержание ТБК-активных продуктов ПОЛ рассчитывали антиоксидантно-прооксидантный индекс (АПИ).

Результаты исследований и их обсуждение. В контроле интенсивность липопероксидации и активность каталазы увеличивались от печени к почкам и легким. После реперфузии конечности в исследуемых органах отмечался рост интенсивности липидной пероксидации, о чем свидетельствовало накопление ТБК-активных продуктов, которое в печени было достоверно больше, чем в контроле, до 14 суток, в легких - до 7 суток, в почках - в течение 24 ч. Активность каталазы в органах была существенно выше контроля во все сроки наблюдения с максимумом через 24 ч. Показатель был достоверно большим в почке. Величина АПИ в почке и легких повышалась до 24 ч после реперфузии конечности и до 14 суток снижалась, не достигая уровня контроля. В печени динамика показателя была колебательной с первым повышением через 1 ч, снижением - через 2 ч и последующим ростом до 14 суток. Приведенные данные указывают на длительное напряжение адаптационно-компенсаторных механизмов, направленных на устранение патогенных факторов, обусловленных наложением жгута, двухчасовой ишемией и последующей реперфузией конечности. Полученные результаты требуют дальнейшего углубленного изучения, однако уже сейчас указывают на опасность двухчасового наложения жгута с позиции системного воздействия на организм и требуют дополнительных мер профилактики и коррекции.

Реперфузия конечности после двухчасового артериального жгута сопровождается длительной активацией процессов липидной пероксидации в печени, почках и легких, проявляется статистически достоверным ростом содержания ТБК-активных продуктов, который в печени превышает контрольный уровень к 14 суткам после реперфузии, в почке - через 24 ч, в легких - через 7 суток. Усиление процессов ПОЛ происходит на фоне повышения активности каталазы во всех органах, которая достигает максимума через 24 ч и не снижается до уровня контроля через 14 суток. Баланс антиоксидантно-прооксидантных процессов в исследуемых органах смещен в сторону усиления антиоксидантных механизмов и указывает на длительный оксидативный стресс в постреперфузионном периоде.

Ключевые слова: жгут; реперфузия; липопероксидация; внутренние органы.

Отримано 10.01.17 